Article

\title{
Reincarnation in America: A Brief Historical Overview
}

\author{
Lee Irwin
}

Religious Studies Department, College of Charleston, 66 George Street, Charleston, SC 29424, USA; irwinl@cofc.edu

Received: 14 September 2017; Accepted: 3 October 2017; Published: 11 October 2017

\begin{abstract}
American theories of reincarnation have a long and complex history, dating from 1680s to the present. It is the purpose of this paper to highlight the main currents of reincarnation theory in the American context, giving a brief historical survey. Sources surveyed begin with Native American traditions, and then move to immigrant traditions based in Western Esotericism, Christianity, Judaism, missionary Hinduism and Buddhism, Spiritualism, Theosophy, Rosicrucianism, and concludes with more current theoretical influences, based in paranormal science research. The paper demonstrates that current theories of reincarnation are increasingly less dependent upon religious support and increasingly based in direct personal experience, paranormal research, and new therapeutic models. The paper concludes with some reflections on the complexity of reincarnation theory and raises questions concerning the future development of such theory.
\end{abstract}

Keywords: reincarnation; rebirth; past life memories; paranormal; out-of-body experience (OBE); near-death (NDE); retrocognition; survival of death; super-psi; regression therapy

\section{Introduction}

While reincarnation theory has a long history in Asian religious traditions, there is an equally long "Western" history, dating back to the early pre-Socratic period in ancient Greece (Irwin 2017). The earliest testimony of metempsychosis (rebirth) among Greek sources is found in the gold tablets of the Orphic tradition (c. 600 BCE) where the psychê (or "soul") was regarded as superior to the physical body, in comparison to the dim "shades" of the older Homeric eidōlon, or "image" that had minimal existence in Hades (Bremmer 1983). This elevation of the psychê was based in an ontological mythos (soma-sema, or "body as prison") that defined soul as intrinsically superior to any form of physical life. Through ritual participation in the mysteries, accompanied by living a just and disciplined life, initiates were "purified" and prepared for an escape from the "circle of necessity" or "wheel of birth" - that is, escape from rebirth in the human world. The Orphic deceased would "fly out of the circle of weary, heavy grief" as indicated by the sacred inscriptions on small gold leaf sheets, rolled into in a cylinder worn on a necklace (Graf and Johnston 2007, pp. 127-28). From this period forward, metempsychosis (rebirth) is a constant theme within the pre-Christian Mediterranean world.

The pre-Socratic philosophers such as Pythagoras and Empedocles taught reincarnation and Plato fully developed an intricate, cosmological theory of rebirth (Johnston 2011; Long 1948). According to Plato, the Creator gave the younger gods the laws by which mortals live where the first birth was the same for all souls (Timaeus $41 \mathrm{~d}-\mathrm{e}$ ). Each soul must then discover love as a mingling of pleasure and pain, fear and anger, and other paired emotions. If these emotions were conquered through love and did not rule a human being, and if he (or she) lived a proper philosophical life, the soul could then return at death to the star from which it came. But a soul dominated by disruptive, bodily passions would be subject to rebirth (metempsychosis) in human or animal form and these incarnations would continue until, with the help of reason, such souls overcame the "turbulent and irrational mob" of 
elemental influences that led to rebirth (Timaeus 42b-e). Thus rebirth, in the Platonic tradition was retributive and escape from rebirth was the ideal, even though eventually, rebirth was possible even for the philosophic soul (Kaplan 1996, pp. 14-17).

Neoplatonic authors further articulated theories of metempsychosis as found in the works of Plotinus where the intellective soul is the noblest aspect of every human being; in this sense, the body in Plotinus becomes only an externalized image of the soul. Every human being for Plotinus is distinctive, a logos (idea) that combines with the archetypal human form in conjunction with parents and location to create a unique individual (Enneads V.7.1). When life is lived through the cultivation of the higher, pure aspect, the soul takes flight to the One in unitary mystical visions; but if lower desires dominate, then reincarnation must necessarily follow in further human lives or possibly in animal lives for the overly sensual (Enneads III.4.2; Sorabji 2005; Remes 2008). Philosophers such as Iamblichus (De Mysteriis Aegyptiorum) and Proclus (borrowing from the Chaldean Oracles) further linked soul development to ritual (theurgy) practices that would, when carried out with purification rites and prayer, assist the practitioner to escape the wheel of rebirth. These theories of rebirth are also linked to an angelic cosmos in which angels may assist the soul to higher life and recollection (anamnesis) of past lives, as in Plato, was a necessary step in attaining escape from rebirth and ascent to a divine, transphysical life (Dodds 1962; Irwin 2017; Rosán 2008).

Greco-Roman theories of rebirth were assimilated into Christian thought, primarily through Origen, whose theory of transmigration became a contested theme within Christian theologies. While Origen did not embrace reincarnation theory, nevertheless he speculated in his writings, that if the soul truly pre-exists, created before the body, then it may take a body or more than one body, as it is the soul which animates flesh in whatever form flesh takes (Contra Celsus I.32). Origen offers the unique idea that the pneumatic (spiritual) aspect of individual identity is capable of reincarnating (metapneumatosis) into another human being. Further, this personalized aspect of spirit, as the "spirit of Elijah," carries with it unique "power" and ability, as possessed by the actual person, and as such is not simply an abstract idea of transpersonal Spirit. Thus, while soul remains as the true source of human identity, incapable of another physical life, a subtle spiritual aspect of that identity is capable of reincarnation into other lives (Détré 2005, pp. 167-203). Origen's concept of preexistent soul marks the beginning of a long history of contestation within Christian theologies that rejected orthodox after-life theories of heaven and hell in Catholic, Eastern Orthodox, and Protestant teachings in favor of a theory of rebirth. Even though Origen's theory of the preexistent soul was pronounced anathema by the Fifth Ecumenical Council (553 CE), diverse Christian groups have continued to teach reincarnation into the present day (Givens 2010, pp. 94-96).

Foremost among those groups influenced by reincarnation theory were a variety of early Gnostic Christian groups (Layton 1987; Logan 1996; Pearson 2007), as well as more mainstream groups such as the Paulicians (fl. 850), the Bulgarian Bogomils (c. 1050), and the French Cathars (c. 1225), all of whom taught reincarnation for those who did not successfully escape the fallen, sinful world through dedicated, ascetic, devotional practices (Irwin 2017). Against this background of resistant Christian theologies, texts traditions that explicitly taught metempsychosis continued to circulate in monastic communities and secular libraries, specifically, the Pistis Sophia, the Kore Kosmou, the Asclepius, and the collected texts of the Corpus Hermeticum. The Pistis Sophia (c. 275 CE), the most explicit Christian text, describes the soul as led, through a series of stages, into the upper cosmos and taken before the Virgin of Light who, seeing it as a sinful soul, determined the bodily form it would take in its next life. The soul was then given over to the receiving spirits who induced forgetfulness and cast it into a certain type of physical body "worthy of the sins it has committed" (Mead [1896] 1989, pp. 233-43).

Various theories of reincarnation continued, based in oral traditions and alternate texts, into and throughout the Renaissance period. The Corpus Hermeticum (Copenhaver 1998), a compilation of 18 short texts that reflect a Greco-Egyptian orientation, was highly popular as an alternate prisca theologia (Walker 1954) claiming to be more ancient than Christianity and offering several theories of reincarnation. The process of rebirth was epitomized in a sacred cup of Nous, a bowl (krater, cup or 
grail), offered to an aspirant who could plunge in (drink) and ascend, returning to source, or who could refuse and be led only by pleasures and desires of the body. Those who failed to drink would "pass through many bodies," through multiple cycles of death and reincarnation, until "leaving the familiar and present," the soul discovered the "ancient and original unity" beyond all bodily forms and attained true knowledge (gnosis) and union with the One (Corpus Hermeticum IV: 5-10; V.2; Copenhaver 1998).

Francesco Patrizi's Nova de Universis Philosophia (1591) was a popular compendium of texts and ideas, including reincarnation, from Hermetic-Platonist sources that traced "ancient wisdom" (prisca sapientia), not from Aristotle, but from the Egyptian Hermes, Orpheus, Zoroaster, Plato and other Neoplatonists, especially Proclus (Leijenhorst 1998). Giordano Bruno (d. 1600) also wrote constructively on reincarnation as a necessary process for soul development through many incarnations. Bruno's theory is complex and based in "fateful justice" for each soul in a search of a more empowered sense of human personhood through a positive relationship with universal soul. Thus, there is only creative ongoing process, no final judgment. Bruno was burned at the stake by the Catholic Inquisition for his refusal to reject these ideas (Mendoza 1995).

During this same period, Jewish Kabbalah was popularized and the theory of gilgul neshamot (revolution or cycles of soul) became increasingly well-known among Christian and Jewish esotericists (Ogren 2009). Many Jewish renaissance writers expostulated on the theme of gilgul or rebirth, perhaps the most influential being a work by Hayyim Vital (d. 1620), a student of Isaac Luria, entitled Sha'ar ha Gilgulim ("Gate of Cyclical Return"). This very long and complex work offers a detailed description of soul cycles embedded in a cosmological theory of reincarnation (Wexelman 1999). Christians, influenced by Jewish Kabbalah and the theory of gilgul, also created works and text compilations in the form of Christian cabala, in which "soul revolution" was amalgamated to theories of resurrection such that the soul would reincarnate until the time the Final Judgment (Karr 2010). By the 17th Century, ideas of soul revolution in England and Europe were accessible and disseminated among Christian and Jewish esoteric theorists (Ogren 2009).

The most pronounced example is found in the first book-length work in English on reincarnation, articulated by the German esotericist Franciscus Mercurius van Helmont (d. 1698) while visiting England (Coudert 1999). Van Helmont was a Christian cabalist and a proponent of an emergent new anthropology arguing in favor of the necessity of "soul revolution" (reincarnation) as inseparable from human "progress" (Coudert 2008). Having read the Sefer ha-Gilgulim, van Helmont constructed a theory of soul evolution, limited to 12 possible incarnations (as in ha-Gilgulim) spanning a period of 1000 years, with at times long "periods of rest" between lives, all directed toward the perfection (or restoration) of the soul. George Keith attended meetings to discuss Kabbalah with Lord Conway and his wife, Lady Anne Conway, at their estate where van Helmont was the visiting physician for Lady Conway. In turn, Keith assembled the discussion notes into a single volume, attributed to van Helmont, entitled Two Hundred Queries Moderately Propounded Concerning the Doctrine of the Revolution of Humane Souls, and Its Conformity to the Truths of Christianity (1684). This is the earliest book-length volume on reincarnation in English (Irwin 2017, pp. 122-24) and consists of specific questions, each answered to show the rational legitimacy of the theory of reincarnation (and the irrational nature of belief in an eternal hell or heaven). George Keith subsequently became the person responsible for the transition of reincarnation theory to America in the 1690s where he wrote and published a pamphlet defending his views (Keith 1692).

\section{American Traditional Reincarnation}

Long before the coming of European immigrants, most native groups held some form of belief in rebirth into the human (and animal) world after death based on indigenous theories of soul life (Mills and Slobodin 1994). Native American soul concepts are complex and diverse; however, all indigenous groups believed in a post-mortem existence, in an afterlife that supported normal cognitive awareness, including a capacity to return to physical human life (Hultkrantz 1953; Hultkrantz 1998). The concept of soul was complex and usually consisted of multiple aspects, rather than being a 
single entity; at death, these various aspects would depart to cosmologically defined domains; for example one aspect was intrinsic to the bones of the dead while another, like the breath of life, would return to the stars. The "free-soul" was that aspect capable of out-of-body journeys, linked to various types of shamanism, and was the aspect that departed to the post-mortem village of the afterlife (Hultkrantz 1953). Reincarnates were often given various names (over many years, through ceremony) that designated both a returned soul and past social accomplishments of that soul. The name was more powerful and more significant than the individual identity that reincarnates; it was the obligation of the person reborn to live up to his or her former accomplishments (Irwin 2017). Among numerous native groups, a disincarnate soul could also be reborn into multiple new bodies simultaneously, indicated by the naming practices, and all identically named individuals were believed to be actual incarnates of that soul (Mills 1994; Stevenson 1975, 1997).

In summary, there are three major perspectives on reincarnation among Native American peoples, especially reflective of traditional, very old beliefs. First, at death there is a post mortem existence that is similar to the physical life lived while incarnated and that return to embodied life is provisional. This provisional aspect is crucial because it clearly expresses the belief that only some individuals return to live additional human lives. A second perspective is that reincarnation is an open choice as is staying in the afterlife world, or a Village of the Dead. A third perspective is the culturally constructed process of naming which predetermines the social location of the returning individual. This social-functional view is strongly associated with either kinship relations or social hierarchy in which names, titles, and status are transmitted through naming rituals. Causality lies not with the shamanic power of the individual, nor with the sacred powers above, but with social practices that determine how a newborn child will fit into existing social roles (Irwin 2017, pp. 21-34).

\subsection{American Esotericism and Transcendentalism}

When George Keith arrived in Philadelphia in 1685, as a convert to the new Quaker movement, he brought with him van Helmont's theory of "soul revolution" (reincarnation) and promoted it among American Quakers (Fisher 1985). Controversy over rebirth split the Philadelphia Quakers, with a smaller group supporting reincarnation theory while the larger group, at George Fox's command, rejected the theory (Coudert 1976). Thus, from the earliest period of immigration the theme of reincarnation became a contested subject, both for Europeans and later native converts to Christianity. The theory of one life, one death, one judgment, and one afterlife as promoted by Christian missionaries, Catholic priests, and Protestant ministers, made reincarnation a liminal theme among mainstream Christians. However, those less identified with mainstream Christianity maintained a consistent dedication to Western esoteric traditions, including esoteric Christian beliefs in rebirth.

Among well-educated individuals the assent to reincarnation was based in the study of esoteric texts (Versluis 2001). This was particularly true among the New England Transcendentalists, most of whom supported the theory of reincarnation. Emerson was an outspoken supporter of the theory, as was Edgar Allen Poe, Walt Whitman, Henry Thoreau, Bronson Alcott, George Ripley, Frederic Hedge, and James Freeman Clarke, among many others (Head and Cranston 1967, pp. 260-339). Emerson's theory is a unique blend of enlightenment rationalism, the perfectibility of the individual, and various esoteric, often Asian, concepts, resulting in an early version of "American metaphysical" beliefs not moored to any specific religious tradition (Albanese 1997). According to Emerson, the "complete human" requires multiple lives that will allow the soul "to drink the healing waters of illumined thought" (Larson 2001). However, this process of progressive discovery is not simply individual but part of a greater "metempsychosis of nature" through which every creature, indeed all of nature, evolves toward its higher potential (Corrigan 2012). However, the process of sympathetic discovery and development has no teleological, predetermined outcome; the long process of incarnations remains open-ended and souls can slip back to former states or cycle in repeating patterns (Obuchowski 1979). Influenced by Goethe's scientific treatises, Pythagorean metempsychosis, Hindu sacred texts (the Upanishads and the Bhagavad Gita), and a host of other esoteric ideas, Emerson sustained a positive belief 
that each textual source could "provide the materials necessary for "progressive" observation and experimentation" that would further promote human development through continued incarnations (Corrigan 2012, pp. 41-42). What was required was a synthesis of both scientific investigation, poetic genius, and a spiritual metaphysic that reflected a "new oldness" that, like the honey bee, could create a sweet metaphysical elixir out of disparate elements (Irwin 2017, pp. 131-35).

In the emergent American context, as illustrated by Emerson, reincarnation shed its classical European alignment with a static, hierarchical ontology and offers a view which is dynamic and historically open-ended. There is forward development but no pre-determined end. The agency for reincarnation is "naturalized" in the sense that deity recedes and natural law implies a cycling of souls whose life conditions reflect past life experience. The goal of human life is not a disembodied ascent to a higher domain, as an escape from physical life, but an emphatic embrace of physical life as the evolutionary locus of embodied consciousness. There is also a participatory theme developed as American intellectuals claimed to recall actual past lives. For example, Thoreau made experiential claims about past lives in his letters and journals, as did Emerson's brother Thomas, the poet Nathaniel Willis, and Louisa May Alcott among others, thus providing a new participatory context for reincarnation theory distinct from any religious beliefs (Head and Cranston 1990, pp. 242-51).

\subsection{The Afro-Caribbean Synthesis}

Another influence in the development of American reincarnation theory derives from the importation of African peoples as slaves into the Caribbean and North and South America. African indigenes had strongly developed, very old traditions of reincarnation as a widely shared belief pattern, particularly throughout West Africa. Reincarnation theory takes a different turn, similar to Native American traditions, through emphasis on the role of ancestral souls. To become an ancestor means to live a long, exemplary life, gaining the respect and appreciation of others. After death, the ancestors assist the living who must remember them with proper ceremony. Rebirth of ancestral persons is usually within the kinship lineage, often skipping a generation, from grandparent to grandchild (Mazama 2002). Social position and status of living individuals is linked to specific ancestral qualities he or she embodies, as recognized through naming practices. The identity of the departed individual retains its primal location in the realm of the ancestors, while various attributes and personal qualities are distributed into the lives of one or more individuals. A given ancestral name represents the ancestral spirit or soul and thus influences the social standing of the individual, particularly if the ancestor was a figure commemorated in ceremony, was head of a household, or held an important title (Mbiti 1970; Onyewuenyi 1996).

Among African slaves, a receding belief in reincarnation is found in various records that constitute the history of slave religion. For example, as recorded from one African American woman named Bell, concerning African American slaves in the 1830s, there was a "universal belief" that "at death they shall return to their own country and rejoin their former companions" (rebirth). Another example is recorded by an African born woman slave "who wished for death" because she believed that "the first infant born into a [African] family ... was the individual come back again" (Raboteau [1978] 2004). Folk tales narrated by African Americans recorded clear beliefs in reincarnation well into the 20th Century, tales particularly congruent with African Igbo beliefs, as argued by Jennifer Hildebrand (Hildebrand 2006). In a collection of folktales gathered by Edward Adams in 1927 among African American Sea Island Gullah and the swamp Congaree of South Carolina, he recorded (in vernacular language) several tales about "transmigration." One tale tells of a "nasty lookin' buzzard" interpreted as the reborn soul of an African chief who sold his people into slavery and who was thus condemned to live many lives eating dead animals. Another tale tells of a giant yellow crane who was the embodied soul of a mulatto doctor, trained in Europe, who was believed to have purposely killed his black patients (Adams 1927). Among the African Igbo, those who committed a crime against the community and who did not emulate ancestral values and behavior were condemned to be a ghost or to be reborn as an animal who could do no harm to humans. 
As slaves developed their African traditions in the Americas, explicit transcultural religions were created based on a synthesis of influences from African, Amerindian, European (particularly Catholic), and post-African creole persons born into the Afro-Caribbean context. The emergent creole amalgamation, that is, the creative integration of diverse elements of class, race, gender, and power, led to a variety of religious syncretic traditions, all embracing various forms of reincarnation theory, best represented by Vodou (Voodoo), Santeria (Lecumi), Candomblé, and Umbanda, all present in contemporary American cities. One shared characteristic of creole traditions can be identified as the belief in a variety of soul aspects making up the person, some elements of which can be reborn in living humans after death (Olmos and Paravisini-Gebert 2003).

For example, Santeria was brought to Cuba by captured Yoruba slaves, where the "saints" tradition was named as Lukumi (Lucumi) or Regla de Ocha (Rule of the Orisha). Human beings, after living a long, natural life with a good death, may become an ancestor (egun) and live in the invisible world, watching over his or her living family. Those best qualifying for ancestral remembrance are those who "fulfilled their destiny" (as in Yoruba belief), contributed to the community, lived exemplary lives, and did not die young or act in cruel or criminal ways. Ancestors are believed to reincarnate usually into their family lineages as a grandchild; however, it is also possible for reincarnation to occur outside the family lineage. Before rebirth, ancestral spirits restore themselves in the "good heaven" (orun rere) while watching over the family, and some may become revered Orisha (spirits). Individuals guilty of crimes, cruelty, theft, slander, of using magic to harm others are not reborn but sent by Olodumare to the "bad heaven" (orun bururu), the place of broken pots which cannot be repaired, and are thus unable to reincarnate (Clark 2007; De La Torre 2004; Sandoval 2007).

\subsection{Spiritualism and Theosophy}

The link between reincarnation and spiritualism (or Spiritism) was primarily through Hippolyte Rivail (d. 1869), better known under his pen name of Allan Kardec, the French esoteric writer on mediumship. Rivail was attracted to "spirit manifestations" as seen and heard in mediumistic sessions, such as those of the American Fox sisters (1848), with rapping, knocking, and moving of objects attributed to spirit presences (Irwin 2017, pp. 168-70). Subsequently, he wrote a series of books based on spirit answers to research questions he asked of several mediums, which resulted in the construction of an explicit Spiritist worldview (1857) in which reincarnation was a central theme. The soul is like an embryonic seed surrounded by the perispirit and then by the body, though the perispirit radiates beyond the body to create a surrounding field (aura). Through multiple incarnations, the perispirit becomes increasingly etheric "until it reaches complete depuration [purification] which is the state of all pure Spirits" (Kardec [1857] 1987), a condition that is more likely to occur on more advanced and etheric worlds than present day earth. The purpose of reincarnation is to "attain perfection" through contributing to creation by assisting in progressive development and by undergoing necessary expiations of impurities resulting from the challenges of embodiment (Kardec [1857] 1987). The length of time between new lives is variable, self-chosen, though at times rebirth becomes a consequence of compulsions based on past deeds. At the time of reincarnation, the spirit can choose the mother, gender, and a body, though a specific bodily incarnation may be imposed if a spirit is "too backward to be able to choose wisely" (Kardec [1857] 1950, p. 149-50, 184).

Rivail's influence in America was extensive throughout the 20th Century, particularly among those interested in mediumship and spirit communications. By the 1860s, there were reputedly over two million American spiritualists, some of whom accepted Kardec's writing as authoritative and many of whom regarded Spiritism as a legitimate branch of international mediumship. An internal conflict around the theme of reincarnation resulted in the formation of the Independent Spiritualist Association which supported the theory of rebirth. When the National Spiritualist Association of Churches (1893) issued a strong counter-statement rejecting reincarnation, the majority of the New York membership withdrew and formed the General Assembly of Spiritualists (1930) which affirmed reincarnation. Spiritism is also integral to various Caribbean island traditions imported into America, all of which 
use Rivail's writings to enhance mediumship practices. Further, these traditions engage guides that are distinctively non-white, that is, African, Indian, and Creole spirits, a phenomenon also found among some Anglo spiritualist mediums. The blurred racial boundaries within certain spiritualist groups allowed for social realignment of minority members by instilling greater moral authority on mediums who could cross racial boundaries in giving advice to clients (Peréz 2011). The threatening impact of reincarnation theories that recognized the spiritual authority of marginal peoples created a climate of resistance. Such theories overturned the social hierarchy, challenged racial exclusivism, and violated the sanctity of the self-assumed superiority of birth, race, and social rank (Irwin 2017, pp. 170-71).

The Theosophical Society was founded in 1875 in New York by co-leaders Helena Blavatsky, Henry Olcott, and William Q. Judge. Synthesizing ideas from Mesmerism, New Thought, European Esotericism, Asian Religions, and Spiritualism, the Society sought to promote Universal Brotherhood and to discover "universal laws" which would explain phenomena found in the history of occultism. Blavatsky, strongly influenced by Asian terminology, offers the following description of the incarnational process: there is "no immediate reincarnation on Earth for the Monad, as falsely taught by the Reincarnationists and Spiritists" (Blavatsky 1882), nor any second incarnation for the perispirit or personal ego, but there are "periodical reincarnations for the immortal Ego" not more often than "once every 1500, 2000, or 3000 years." The jiva or "incarnating entity" at the death of the body cannot assimilate to the higher Immortal Ego (manas) and subsequently, is unfit for Devachan, the eternal domain of the manas. The "personal ego" must perish as a slowly dissipating image "reflected in the mirror of Astral light." Only through a "series of rebirths" of the Immortal Ego is it possible for a human being to (eventually) attain "physical, moral, and spiritual perfection" (Blavatsky 1882). Blavatsky offers the interpretation that human development and perfection necessarily occur in stages of incarnation, over a long period of time, never allowing, like Rivail, for regression to lesser states. Other Theosophists, such William Judge, founder of the American Theosophical Society (1895), Gottfried de Purucker, head of The Theosophical Society in Pasadena, California (1929 to 1942), and many others built on the early rebirth theories and assimilated evolutionary theory into their reincarnation models in an attempt to bring Theosophical theory into alignment with some aspects of current, post-Darwinian science. The best assimilation is found in (Judge [1893] 1987) whose book is complex and engaging as well as being one of the earliest English books on reincarnation theory (Irwin 2017, pp. 174-81).

\subsection{Occult Science and Esoteric Groups}

In 1882, the Society for Psychical Research (SPR) was formed in Britain to undertake scientific inquiries into a variety of psychic abilities, primarily those manifest in mediumship, such as transference (telepathy), hypnotism, mesmeric trance, clairvoyance, past-life recall, and interaction with post-mortem entities such as apparitions and ghosts. In 1885, the American Society for Psychical Research (ASPR) was formed in Boston with the support of William James, as Chair of the Committee on Hypnotism and of the Committee to Investigate Mediumistic Phenomena. In 1889, the ASPR became an affiliate of the SPR, forming a joint research agenda to explore psychic or paranormal phenomena such as reincarnation and information gained through mediumship (Taylor 1999). Founder of the American Institute for Scientific Research (1904), James Hyslop in 1905 absorbed the ASPR into his own organization, forming a separate section dedicated to the study of "all claims to supernormal abilities." In discussing reincarnation, Hyslop identifies Plato as the primary source for the theory, linked with other Greek philosophers through a commonly shared conception that "substance is imperishable and passes from generation to generation constituting the matter out of which the individual is made" (Hyslop 1906). Posited as a "universal law" in Greek philosophy, the theory of imperishable substance established for Hyslop an ontological principle of nature as underlying the more explicit belief in metempsychosis in which the surviving entity was a reconstruction from the underlying universal "substance" constituting the human species. No "individual" survived, there was only a newly created entity without memory or knowledge of any previous existence (Irwin 2017, 
pp. 189-90). From this time forward, reincarnation would be increasingly investigated within the context of paranormal research.

During this same period, esoteric American groups also promoted reincarnation as part of higher degree teachings. Early Masonic literary sources for reincarnation, or metempsychosis, reference Pythagoras, the Greek mysteries, and the later Neoplatonists as examples of "ancient mysteries" linked to the archetypal origins of Freemasonry. For example William Preston, in Illustrations of Masonry (1772), refers to the "philosophical notions of Pythagoras" as including a doctrine of "metempsychosis or transmigration of souls into different bodies" and to the belief that "as the soul was of celestial origin and could not be annihilated, and therefore, upon abandoning one body, it necessarily removed into another and frequently did penance for its former vicious inclinations in the shape of a beast or an insect, before it appeared again in that of a human creature" (Preston 2016). According to Albert Pike (1872), the famous Freemason author, the 17th York degree of the Knight of East and West, is based on the doctrine of rebirth, as is the 24th degree, the Prince of the Tabernacles, where he notes the importance of the teaching of metempsychosis as taught in the "Indian mysteries" and the fate of the soul to reincarnate in order to atone for sins that could only be overcome by "voluntary penance" in the form of another physical life (Pike [1872] 2005). Ideas borrowed from Jewish Kabbalah, such as gilgul (rebirth), are also found in Masonic teachings (Irwin 2017, pp. 192-94).

Of all esoteric traditions, the most consistent in teaching reincarnation are the various American Rosicrucian orders, all of which currently promote multiple human rebirths. Paschal Randolph (Fraternitas Rosae Crucis (FRC), 1861), Freeman Dowd (FRC, 1897), Max Heindel (Rosicrucian Fellowship (RF), 1909), and H. Spencer Lewis (The Ancient Order of the Rosae Crucis (AMORC), 1930) all wrote formative, detailed works on reincarnation. In terms of American esoteric theories, the Rosicrucian (RC) orders have consistently supported the theory of rebirth through membership instruction in "higher grade teachings" similar to those noted by Pike in the more advanced Scottish Rite grades of Freemasonry. Randolph published a work on afterlife and rebirth entitled Dealings with the Dead (1862), the same year that he formed the first American FRC lodge in San Francisco. In this work, Randolph offers a remarkable, creative account of the afterlife and transmigration, based in what he claims as direct visionary, participatory experience. The core of Randolph's theory is the monad, a term he consciously borrows from Leibnitz, where every "soul seed" is an immortal, indestructible monad whose "soul form" is a winged globe and whose origin is the "Eternal Heart" or Divine Mind (Randolph [1862] 2012).

Through "stages of unfolding," each soul, reflecting a divine origin, seeks to overcome lesser entrapments and, as "developing monads," to become fully conscious beings in human form (Randolph [1862] 2012). Thus, all human souls "transmigrate" through multiple species and forms (as retained in soul memory) in relationship to a cosmic process of progressive complexity in development. The monad takes a series of progressive forms—-minerals, plants, animals—and, in the process, does not lose its inherent divine nature, which can only be fully known in its human form. Subsequently, a soul can take multiple human forms as it seeks to fully realize its latent divine potentials. Randolph's pre-Darwinian theory maintains that the human soul is present in, but distinct from, each of the embodied forms. In a high enough stage of development ("soul vastation"), the conscious soul can rise to full self-awareness and enjoy conscious existence in the post-mortem state, not necessarily returning to mortal form. Only those lacking fully conscious awareness must reincarnate (Irwin 2017, pp. 194-99). Freeman Dowd further developed and routinized these ideas as foundational to FRC teaching in the present.

Both Max Heindel (b. Carl von Grasshoff) and H. Spencer Lewis likewise developed foundational teachings in which reincarnation is intrinsic to the cosmological order in a generally evolutionary process of human development. Heindel has a highly complex cosmology (1909) that emphasizes multiple stages of soul incarnation, through multiple worlds in a long series of physical lives, each requiring the interaction of multiple psychic vehicles that are necessary to sustain each new material body. These vehicles consist of four distinct aspects, or "higher bodies," each with its own unique 
characteristics—-the vital-etheric body, the desire body, the mind, and the Ego (Heindel [1909] 1973). Ego is the core of the God-created pure, virgin spirit but has lost awareness of its divine origin, enfolded into the various subtle bodies over millennial cycles of involution. Ego must undergo multiple rebirths "to gather experience" in order to reclaim and affirm the divine nature of soul's origin (Irwin 2017, pp. 199-202).

Spencer Lewis (1930) wrote an entire work on reincarnation in which the evolutionary cycle of the soul, from birth to rebirth, has two phases: the Mundane phase from birth to death, and the Cosmic phase from post-death to rebirth. At birth, the entering soul is "an aggregate of personalities" composed of the essential elements of all previous personalities. Out of this aggregate, a "present personality" is formed, representing a current incarnation, strongly informed by past skills, knowledge, and beliefs. In a present lifetime, new experiences, beliefs, and attitudes are formed to further soul development (Lewis [1930] 1956). At death, or "transition," the soul withdraws with its light and aura properties into the Ego identity of soul (consisting of mind, memory, and personality) and is absorbed into the Oversoul, leaving the body to decay and disintegration. The transphysical Ego-souls of the departed dwell in one of twelve Mansions of the Soul, each of which is "given various names and allegorical representations" (Lewis [1930] 1956). Here Ego-souls receives knowledge and Divine benedictions, knowing they must return to incarnation in accord with the Law of Compensation (karma) in a long cycle of multiple lives meant to actualize progressive soul development (Irwin 2017, pp. 203-5).

\subsection{Asian Influences: Hinduism and Buddhism}

The topic of Asian influence in America is highly complex and cannot be easily summarized in a review article. There are at least three primary vectors for the infusion of Asian ideas of reincarnation in the American context. The earliest influence is text translations which were first popularized by the New England Transcendentalists through journal publications like The Dial. In 1842, they began publishing "Ethnical Scriptures," highlighting Asian texts like the Manu-Samhita (Laws of Manu), which explicitly mention "transmigration" of the soul and the consequences of rebirth resulting from previous actions in a former incarnation. Many other Asian texts with rebirth themes were published in translation for various volumes of The Dial (Fuller 1843-1844). In 1843 the American Oriental Society was founded, and in the following year, produced the first edition of the Journal of the American Oriental Society (JAOS) which also published translated Asian texts with reincarnation themes (Salisbury 1847; Jackson 1981, pp. 180-82). Another good example of Asian textual resources relevant to theories of reincarnation is found in the compilation of the Sacred Books of the East (1879-1910) under the direction of Max Muller. Volume one of the series starts with a fully annotated English translation of five major Upanishads, and is followed by nineteen more volumes of Hindu texts, ten volumes of Buddhist texts, and three volumes of Jain texts (Muller 1879-1910). The growing field of Asian studies also produced texts; for example the Harvard Oriental Series published many scholarly text translations from Indic classical religious literature (Jackson 1981). Increasingly, American publishers discovered a growing market for Asian texts, eventually leading to an increasingly rich array of texts, many promoting reincarnation (Irwin 2017). Additionally, Christian missionaries to Asian countries also wrote descriptions of Indic religious beliefs and later shared those descriptions in a variety of public forums.

A second influence developed through esoteric interpretations of Asian ideas assimilated from text traditions but then amalgamated into popular forms of American "Hinduism" or "Buddhism" based on a synthesis of occult ideas and piece-meal borrowing from Asian traditions. For example, Charles Johnston, a professed Theosophist and an immigrant to America, translated numerous Sanskrit texts, many with materials on transmigration, as well as his more relevant work The Memory of Past Births (1899), one of the first texts written on the topic of past-life memory recall (Johnston 1899). In this volume, Johnston describes the soul's journey to Devachan, the higher Theosophical plane of soul renewal, and then its return to rebirth where "its affinities draw it to that land, and class, and family 
whose life is most in harmony with its own nature" (Johnston 1899, p. 8). As a result of the "great law of Karma" the soul must then undergo various trials and events based on past actions, including the necessity of lives in both male and female bodies (Irwin 2017, pp. 213-14).

Another such example. is William Walker Atkinson (writing as Swami Ramacharaka) who published over thirty volumes under various "Hindu" authorial names, primarily on divination and mediumship. In 1908, Atkinson published Reincarnation and the Law of Karma (under his own name) a work reflecting an eclectic blend of American occult beliefs strongly informed by Theosophical theory and key ideas from classic Hindu texts. The strength of Atkinson's book is not in the rather vague Hindu references, but in his review of various rebirth theories or terminologies, and in his ability to summarize and compare those theories (Atkinson 1908).

The third stream of influence is found in indigenous teachers from India, Southeast Asia, and primarily Japan, first represented in 1884 by the Indian author Ram Chandra Bose when he published his work, Hindu Philosophy Popularly Explained: The Orthodox Systems, in both London and New York City (Bose 1884). Bose's account is detailed, rich with newly translated Sanskrit-to-English texts, and very readable. As an early resource for Hindu theories of rebirth and transmigration in the American context, he offers concise definitions of differences between the Indian philosophical schools and does so with direct primary text citations. In September of 1893, the World's Parliament of Religions was held in conjunction with the Chicago Columbian Exposition; this event marks the beginning of popular, charismatic indigenous teachers of Asian religions in America. In Swami Vivekananda's opening address at the Parliament, he specifically addressed the theme of reincarnation. He writes, every human being is a "spirit living in a body" and, while every physical body dies, the "I" will not die, but continues on; there are "two parallel lines of existence, one of the mind, and one of the body" (Ellwood 1987). While bodies may inherit "certain tendencies" from parents (genetics), it is the condition of the soul, based on past actions, that leads the soul to take on a particular body following the "law of affinity," which "is in perfect accord with science," as a result of former habits and patterns of repetition (Ellwood 1987). In 1897, Swami Abhedananda, appointed by Vivekananda, began a twenty-five-year tenure in America as resident teacher of Vedanta, during which time he wrote a small work entitled Vedanta Philosophy: Five Lectures on Reincarnation (1907). This work gives an excellent account of Neo-Vedanta philosophy of rebirth as a "rational and scientifically congruent idea," and Swami Abhedānanda argues persuasively for a convergent theory of scientific evolution and Vedanta teachings on the inevitability of rebirth according to laws of cause and effect (Abhedananda 1907).

Perhaps the most influential individual in popularizing traditional Indian ideas on reincarnation in America was Paramahansa Yogananda, founder of the Self-Realization Fellowship (1920). Yogananda was one of the first Indian teachers to live in America, where he resided for over 30 years, primarily in the SRF retreat center in Encinitas, California after 1935. His very popular work, finished toward the end of his life (1946), Autobiography of a Yogi (1979), an all-time best seller, remains in print to this day. Yogananda explains the teachings of his guru Sri Yukteswar that after the death of the physical body, the soul takes on an astral form (with its implicit casual body); what maintains the interconnectedness of the three bodies (physical, astral, causal) is the "power of unfulfilled desires," and each domain has characteristic desires. Physical body domain has desires "rooted in egotism and sense pleasure," while astral desires "center around enjoyment of etheric vibrations, music of the spheres, and the phenomenal play of light energies and the process of manifesting diverse etheric forms" (Yogananda [1946] 1979). Causal desires "are fulfilled by perception only" and beings who focus primarily in this domain are co-creators with divinity, helping to manifest the "dream-ideas of God" (Yogananda [1946] 1979). The highest, supreme accomplishment is to transcend the casual body, and by reaching complete and total desirelessness, shedding all bodies, to merge with the Immeasurable Fullness, the One Cosmic Ocean, to become one with the Ineffable Ever-Existent. Based on karma, individuals must reincarnate in this world, or other subtler worlds, in order to reach the highest goal (Yogananda [1946] 1979).

In Buddhism, the same historical influences can be tracked: Buddhist text translations; esoteric influences amalgamated by various non-traditional teacher or writers claiming knowledge of Buddhist 
theories of reincarnation; and actual indigenes from India, Tibet, Southeast Asia, and Japan acting as charismatic proponents of Asian ideas of rebirth. Texts such as Sir Edwin Arnold's The Light of Asia: The Great Renunciation (1879), on the life of the Buddha, certainly popularized ideas of reincarnation. Throughout the work, references are made repeatedly to rebirth, including the Buddha's former lives, the "wheel of change" or rounds of many painful births and deaths, and the realization of how these rounds or rebirths are ended in Nirvana (Arnold 1879). As early as 1878, Rhys-Davids offered an English translation of the many past lives of the Buddha (Buddhist Birth-Stories: Jataka Tales), and his work Buddhism: Being a Sketch of the Life and Teachings of Gautama (1912) also includes discourses on past lives (Rhys-Davids [1877] 1912, 1878). Henry Warren's collection of Pali texts has a central section on "Karma and Rebirth" that gives a substantive basis for Buddhist theories of rebirth (Warren [1896] 1922). Buddhist text translations increased over time and offered explicit themes on reincarnation based in various ethnic traditions intrinsic to the history and spread of Buddhism.

Individuals claiming esoteric knowledge of Buddhism are also apparent. Henry Steel Olcott's Buddhist Catechism (1881) was a very popular pro-Buddhist work and widely read not only in America (40 editions) but also in Europe, Japan, and other Asian countries. Olcott's vision of Buddhism was imbued with his own belief in "core tenets" as definitive for every religious worldview and illustrated through a series of rational, demythologized questions, with replies bolstered by frequent references to the Pali canon (from English translations) and further supplemented by references to Western science. The primary cause of rebirth, according to Olcott, is "unsatisfied desire" and an "unquenched thirst for physical existence" impacted by the degree of "individual merit or demerit" earned in the previous lifetime and leading to either a good rebirth or one "wretched and full of suffering" (Olcott [1881] 1886). The theory of "soul" as an immortal entity is repudiated ("that which is subject to change is not permanent"), and the "person" is defined as "an aggregate of five qualities (skandhas)" shaped by karma. The reborn individual is not an immortal soul but "new aggregation of Skandhas" that reflect constant changes throughout each life, shaped by merit and demerit, leading to a new life formed as a "consequence of his action" (Olcott [1881] 1886). The goal of Buddhism is, however, to escape rebirth and attain the realization of Nirvana, which Olcott defines as perfect rest, cessation of changes, absence of desire (Irwin 2017, pp. 234-35).

As with Hinduism, the Buddhists were also represented at the Chicago World Parliament of Religions in 1893, notably Anagarika Dharmapala (Theravada Buddhist) and Soyen Shaku (Rinzai Zen master). In Dharmapala's Parliament address, he references rebirth and notes that "until you realize Nirvana, you are subject to birth and death. Eternal changefulness in evolution becomes eternal rest ... there is no more birth, no more death" (Dharmapala 1999). Rebirth is here linked to evolutionary theory, and progress culminates in Nirvana, thus linking Buddhist stages of rebirth to a generic science concept, illustrating a contemporary theme in Buddhist thought as rational and scientific. However, the most influential individual in popularizing Buddhism in America was Dr. Walter Evans-Wentz, an American follower of Hinduism and yoga, who edited a series of translated works from Tibetan (1927), the most well-known of which is The Tibetan Book of the Dead: Or The After-Death Experiences on the Bardo Plane (Evans-Wentz [1927] 1960).

While the Tibetan Book of the Dead or The After-Death Experiences on the Bardo Plane, is "fraught with problems, errors in translation, inaccurate dates, misattributions of authorship, [and] misstatements of fact" (Lopez 2011), it is nevertheless a classic, popular text on the afterlife and the process of dying, transition, and rebirth that has influenced many generations of American readers, including scholars and Tibetan teachers, selling over 500,000 copies. This work is too complex to summarize but it is a text that gives credibility to the processes of dying, staged afterlife transitions, and rebirth choices based on karma and initiate training. A substantive review and analysis of the text can be found in Irwin 2017. While the Tibetan Book of the Dead now has many diverse translations and an entire scholarly literature bolstering a variety of "Tibetan" interpretations, usually subject to various Western perspectives on the text, the Evans-Wentz version remains the classic "esoteric" account of the Tibetan theory of death and rebirth (Lopez 1998). 
A final example of metaphysical eclecticism in the Asian context is a work by Manly Palmer Hall, Reincarnation: The Cycle of Necessity (1999). In a broader sense, Hall's well-known syncretic construction, The Secret Teachings of All Ages (1928), epitomizes the esoteric metaphysical tradition in America as a synthesis of classic texts, ranging from Plato to his present day, including over 600 text references from alchemy, Gnosticism, Hermeticism, Rosicrucianism, Freemasonry, magical lodges such as Golden Dawn and Anthroposophy, as well as research from anthropology, myth and symbol studies, comparative religions, Asian traditions, literature, philosophy and science. Hall demonstrates with great panache the textual influences that became primary resources for the construction of "ancient wisdom" as a perennial secret tradition "concealed within the rituals, allegories and mysteries of all ages" (Hall [1928] 2010). Taking the stance that reincarnation is an ancient mystery teaching, universal in its articulation through a multitude of cultures, he gives an historical overview of the belief as originating in India and most clearly expressed in Buddhism. He makes a crucial distinction between East and West- "the Western school accepts reincarnation as a means of unfolding the individual while the Eastern school accepts reincarnation as a means of eliminating the individual" (Hall [1939] 1999, pp. 47, 38). The "fundamental impulse" of the law of rebirth is to make "the present inadequacy unbearable" through a deep aspiration to greater perfection. The highest perfection is nirvana, which ends the cycles of necessity and which Hall defines as "an experience of the final personality returning to the unconditioned consciousness of the entity itself" - not the end of evolution, but the end of evolution "as we know it" as incarnate physical beings (Hall [1939] 1999, pp. 163-74; Irwin 2017, pp. 247-51).

\subsection{Esoteric Christian Reincarnation}

While normative Christianity has denied reincarnation, there is nevertheless a long unbroken history of writings on rebirth by Christian authors that extends from the Gnostics to medieval theories into present day America. An excellent example of this trend is a work by the Protestant theologian James Pryse, Reincarnation in the New Testament (1911). Pryse offers the view that a human being has three bodies-physical, psychic, and spiritual—and that each body corresponds to its appropriate world-material, etheric, and heavenly-while the deepest center of soul, the Self, is "identical in essence with Deity" (Pryse 1911). It is the material and psychic aspects that relate to reincarnation or the "wheel of birth" (James 3: 6), while the essential Self is ever free and divine. The soul retains all memory of past lives, but recall by the "external consciousness" can only succeed if the outer life is purified to such a degree that it correlates with the inner reality of the deeper Self (Pryse 1911). He describes Jesus as the "son of David," indicating that Jesus is King David, therefore Abraham reborn, and that Peter is Jonah reincarnated. The reference to "the generations that will not pass away until these things come about" (Matthew 14: 34) refers to the necessity of reincarnation, as those souls with Jesus must be reborn until the full realization of his end-time promises (Pryse 1911).

Another Christian author writing on reincarnation is Ray Goudey, Reincarnation: A Universal Truth (1928). This volume is a summary overview of early 20th Century metaphysical ideas, centered on Christianity in conversation with other religious traditions, scientific research, and popular press accounts of participatory encounters. The human construct is a layered entity with spirit inmost, encompassed by soul, which contains memories of all past lives, united with a characteristic mental body, emotional body, and physical body, for each lifetime. The immortal monad is indestructible and capable of "continual progress upward and onward" and requires multiples lives in both male and female bodies to develop sensitivity and perspectives on both bodied ways of life (Goudey 1928, pp. 43-46). The heart of the book is an analysis of Christian beliefs in reincarnation as held by specific individuals, primarily Church Fathers, Catholic and Orthodox, including "non-orthodox" Christians found among the Gnostics, Basilidians, Valentinians, Marconites, Manicheans, and Essenes-all as groups who promoted theories of reincarnation. Taking an esoteric Protestant view, he then plunges into "Biblical evidence" and examines over 50 references in the Christian Bible, which he interprets as confirming a belief in reincarnation (Goudey 1928). 
The actual history of Christian reincarnation theory in the 20th Century is dense and complex, heightened by a new element, the participatory account of select mediums and psychics who draw upon personal intuition as much as scripture for authentication. Edgar Cayce (d. 1945), a deeply committed Christian, epitomizes this metaphysical trend. Cayce became an early classic example of an American medium who validated reincarnation through his own and others' (about 2500) past life readings (Cerminara 1950). In Cayce's theory of reincarnation, the "soul-entity" is shaped by two fundamental influences: karma and the "ideal" that guides and inspires each soul. The "ideal" is primarily informed by foundational Protestant Christian virtues and "Christlike" attitudes that emphasized working for the good of others, through healing, charity, kindness, and love (Cerminara 1950). The "person" is a conjunct of body, mind, soul, and a divine aspect that motivates actions according to inherent purpose (a positive Christian world) and undergoes development through multiple lives, every aspect of embodiment etched in detail in the indelible Akashic records (Irwin 2017).

At death, the soul-entity ascends to a higher state where it becomes "superconscious" and more ecstatically self-aware. At rebirth, the higher conscious mind reverts to a subconscious state while all past knowledge remains identified with the superconscious state (as repressed past-life memories). The newly embodied individual thus acquires a new, unformed conscious mind identified with a new body that is only vaguely aware of the deeply quiescent, now latent superconscious mind (Smith 1989). Casey also gave detailed accounts of seven of his past lives and described his relationships to others in terms of "group soul" relations extending over thousands of years (Langley 1967).

In 1949, The Order of Christian Mystics published a collection of four essays by the founder, F. Homer Curtiss on reincarnation. He defines reincarnation as "the repeated, cyclic embodiments on Earth in human form, of the same Spiritual Being or individual Soul. In thus incarnating you do not become someone else but are always yourself" (Curtiss 1949, p. 10). He bolsters this definition by citing Hindu scriptures (Bhagavad Gita), though he repudiates the "repulsive doctrine" of transmigration of soul to animal reincarnation. He notes that it is not the "personality" which reincarnates, but the "spiritual self" as an "incarnating Ray upon which all the transient personalities are strung" (Curtiss 1949, p. 11). Curtiss lists primary reasons for reincarnation: a single life is too short for the realization of one's chosen destiny or desires; to prove through trial the lessons learned in previous lives; to redeem past mistakes and reap rewards from good deeds; to continue strong ties of love and companionship and secure forgiveness to others for past harms; and to radiate the Christ-force to advance evolution (Curtiss 1949, pp. 22-24). Curtiss contends that his interpretation of reincarnation is perfectly consistent with Christian teachings. Using biblical citations and referencing early church fathers, he argues that a just God has created a world that requires multiple incarnations in order for all peoples to hear the teachings of Christ and then to live up to those teaching through multiple incarnations leading to spiritual perfection.

In the post-World War II context, the theory of reincarnation continued to grow and gain increasing numbers of adherents among Catholic, Protestants, and Evangelical Christians. In a 2009 PEW survey of American religious beliefs, 22\% of Christians confirmed belief in rebirth (PEW 2009). Two prime examples from this period are Dr. Quincy Howe Jr.'s Reincarnation for the Christian (Howe 1974) and Dr. Geddes MacGregor's Reincarnation in Christianity: A New Vision of the Role of Rebirth in Christian Thought (MacGregor 1978). These authors are academic scholars; Howe taught classics at Scripps College and MacGregor was a distinguished professor of philosophy at University of Southern California. Both books have been, and continue to be, popular and easily available and are written as an appeal to Christians to rethink theories of afterlife and post-mortem events. Both promote a point of view that reincarnation is completely compatible with a liberal interpretation of scriptures and with normative doctrines within a wide range of Christian denominations. Both are explicitly historical, contextualizing reincarnation theory as an implicit teaching of Jesus repressed by institutional churches to better support ecclesiastical power and social control; both draw on comparative (Asian) religious 
sources to bolster their theories. And both authors claim to be devoted Christians whose education led them to believe that rebirth is a rational and believable doctrine (Irwin 2017, pp. 264-68).

A final example is a work by Elizabeth Clair Prophet, Reincarnation: The Missing Link in Christianity (1997). Her esoteric message (received through mediumship) on Christianity and reincarnation is an engaging review of contemporary theories in biblical criticism, allied with interpretations of scriptural passages written to show the "secret teachings" of Jesus as similar to teachings found in select "Gnostic" texts. One of the few esotericists who has incorporated biblical criticism into her theory of reincarnation, she recreates the Jesus context in concord with contemporary scholarship on the life of Jesus and uses copious references from the Dead Sea Scrolls, the Old Testament Pseudepigrapha, the Nag Hammadi texts, and other early non-canonical text sources to support her theory, as well as materials from current parapsychological research (Prophet 1997).

She presents Jesus as "an esoteric wisdom teacher" whose "secret teachings" were directed toward the attainment of gnosis and the soul's union with God, as reflected in specific Gospel passages, further amplified by references to Gnostic texts. The human sojourn in the world may require many lifetimes or rebirths to reach the necessary degree of purity for attaining mystical insight that leads to "resurrection"—-defined as direct mystical knowledge of God in the present lifetime. She also places emphasis on the "body as prison" (soma-sema, citing Neoplatonism) as a true description of the material world incarnations where attachments to "transitory [worldly] beauty" draws the soul back into new bodies. The challenge of rebirth must be overcome through four basic aspects: fulfilling all karmic obligations; identification with the true spiritual self; receiving divine grace that awakens a person to spiritual practices; and focusing "all your mind on the purpose of reunion with God." According to Prophet, only when karma is "balanced" can a person "find the nonlocal state, the kingdom of God," (referencing quantum theory) and attain liberation from rebirth (Prophet 1997, pp. 298-318).

\section{Trans-Traditional American Reincarnation}

While strictly fictive accounts of "past lives" are too numerous to survey, nevertheless such narratives introduce the theme of multiple past lives as imaginative constructions in a variety of genres whose authors mix fictive narratives with past life claims. Such claims are often interwoven with participatory encounters that combine déjà vu, past life memories, dreams, visions, and intuitive perceptions with imagined constructions of alternate lives in distinctive social or cultural settings. These "spiritual autobiographies" of past lives in storied form, imaginatively reconstructed and given legitimacy through claims of evidential memory and detailed information of the period, represent a new genre in reincarnation theory. They also set the stage for the popularization of reincarnation in a variety of media whose readers increasingly seek more information and rebirth stories based in popular claims of direct personal experience. The tendency that manifests is an interesting mix of imagination, memory, creative fiction, and revelations about human existence no longer reducible to any religious theory but often eclectic and, at times, eccentric and individual (Irwin 2017, pp. 295-96).

Augustus Marion Fulk, a highly-respected Arkansas judge from a distinguished family of lawyers in Little Rock, is an excellent example of the syncretic, imaginative, and eccentric. Fulk's work, Reincarnation: Time, Space, Matter (1940), is a large, dense volume which offers a unique American account of rebirth that is philosophical, scientific, and "divorced from religion" (Fulk 1940, p. 13). While Fulk's theory is highly idiosyncratic, it represents a strong commitment to "a priori" intuitions based on his personal past-life knowledge (rather than past-life memories), aligned with theories in science (particularly physics and astronomy), without reference to any esoteric school of thought. However, in many ways his theory is alchemical and hermetic, as it describes a reiterative structural set of correspondences from the eternal atom of the soul, through the periodic table, processes of nature, the person, the world, the solar system, the galaxy, to the macrocosmic universes in an infinite scalar system. While the system is much too complex to fully summarize (Irwin 2017, pp. 297-300), Fulk's work is based on his creative interpretation of the periodic table and atomic structure as a basis for a cosmic model of interlinked, scalar universes from the smallest to the largest. 
The narrative is a series of reflective essays on the imagined significance of proton and electron configurations of the elements as a base model applied to human life and soul existence; as an imaginative construction, it is a unique synthesis of science theories and intelligent, eccentric ideas. Fulk clearly professes an early form of process theology; as souls evolve within the vastly contained universes of Being, through the agency of all souls, Being also evolves. In this divine process, every human being has a soul, a divine atom which is a "round objective reality containing subjective knowledge" and which is enhanced and developed over many lifetimes (Fulk 1940). Through recurrence, the soul retains and enhances specific contents of knowledge, which is forever held within the vast and immortal sphere of the soul particle. Reincarnation describes this process of gradual development through learning, lived experience, and integration; only through recurrent processes of life embodiment (rebirth) can the soul develop, just as God develops through the lived knowledge gained by every soul. Human a priori insight is the surfacing of that innate knowledge of soul, bringing forth past insights in relationship to new discoveries and needs. Thus, it is not "past life memories" that matter but past insights and knowledge that can, often unconsciously or as recovered in dreams, be applied to current desires and circumstances (Fulk 1940).

Another example of creative, fictive construction of reincarnation is found in L. Ron Hubbard, founder of Dianetics (1950) and the Church of Scientology (1953). The goal of the Dianetic therapy is to produce a "clear," defined as a person who has been "audited" to rid him or her of all traumatic "engrams" that reside in cellular memory acquired in traumatic circumstances, starting with prenatal traumas. The relevance of Dianetic theory to reincarnation is that when auditors (who direct the clearing process) identified past traumas in preclears, they discovered that imprints were attributed to past-life events. This opened a new field of inquiry which Hubbard addressed in The History of Man (2007). The theta, or soul, as the main target of auditing, is the " $\mathrm{I}$ " of the preclear, the true core identity of the person; "it is immortal and cannot die" but may succumb to deep conditioning by cellular memory or injected entities ("subpersonalities") and may be "asleep" and unrecognizable by the conditioned, conscious personality (Hubbard [1950] 2007). Thus, the individual incarnate is a combination of a "genetic being" and a "theta being," each with its own time track, the genetic representing the protoplasmic, genetic species evolutionary line and the theta representing a transphysical, psychic line combining with a different genetic line in every incarnation. Hubbard also notes that at death the theta goes to the "between-lives area" (usually Mars) where it reports in and is given a "strong forgetter implant and is then shot down to a body just before it is born" (Hubbard [1950] 2007). The elder phase of a "second childhood" is a prelude, reconstituted from theta memory, of the forthcoming death and rebirth (Irwin 2017, pp. 301-3).

Paul Twitchell, founder of Eckankar, is another example of an American spiritual teacher who embraced India as the source of wisdom but who then adapted his message based on his own out-of-body experiences (Twitchell 1969). Influenced by the Hindu teaching of Yogananda and later by Kripal Singh, a master in one of the Sikh lineages and founder of Surat Shabd Yoga (which teaches out-of-body projection), Twitchell constructed his theory of reincarnation as "ancient teaching" that he learned through soul travel. According to Twitchell, all humanity is linked through karmic bonds and every individual action affects the whole; thus the "law of Karma" is the "underlying principle of human responsibility" (Twitchell 1969). As the "fruits of action" are inescapable, they determine rebirth and events in future lives. All karmic obligations and consequences are stored in the Karan Sarup, the causal body which "never makes a mistake" recording deeds, and which requires that all karmic debts on the physical, astral, and mental planes be paid off on the plane to which those debts correspond. Those with very good, excellent karma will rise above these lower planes and ascend to higher planes in the "fifth world;" this is liberation, a return of the soul to God, the primary goal of Eckankar (Twitchell 1969; Irwin 2017, pp. 286-88). 


\subsection{Paranormal Science and Popular Rebirth Theories}

A new approach to reincarnation theory began in 1960 when Dr. Ian Stevenson published his first article on the subject, offering evidential information. Chairman of the Department of Psychiatry at the University of Virginia in 1957, and later the founder and Director of the Division of Perceptual Studies (1967), Stevenson published prolifically on reincarnation and wrote many articles and books which have become classic examples of an evidential approach founded primarily upon material gathered from young children who claimed to recall past lives (Stevenson 1966). Stevenson assembled "cases of the reincarnation type" (CORT) that focused on children between the ages of 2 to 6 years old, who spontaneously claimed an identity as a "previous personality" who had lived before his or her current life. By 1966, he had gathered detailed information on 600 such cases, including cases in which he interviewed the children himself; by the end of his research he had documented over 2500 such cases.

In 1983 Stevenson analyzed 79 cases of past-life memory in American children, claiming that this is the first report of such cases (Stevenson 1983). He discovered that around three years old (the mean), an American child begins to claim memories of a past-life, giving proper names or persons and places, including the mode of death, and then around six to seven years old, ceases to mention these claims. The child also demonstrates unusual behaviors that often correspond to the behaviors of the claimed past-life individual or, in Stevenson's term, the "previous personality." Often parents claim that they do not know and have never heard of the claimed former personality; children may give up to 50 details of the previous personality and many of these are verifiable. Of the 79 American cases (43 male and 36 female), only 16\% of the parents in 56 cases claimed to believe in reincarnation ( 23 cases could not be assessed), the other parents made no such claims, and many had never heard of reincarnation as a possible afterlife theory. In most cases, parents denied the validity of the rebirth, usually not taught by their religion, and often chastised or punished their child for claiming such memories (Stevenson 1983). In many ways, Stevenson's research marks a watershed in reincarnation theory, as it moves the center of focus away from a religious context entirely and relocates the center in an academic, evidential program of investigation.

In counterpoint to the development of past-life research in the academic context, popular American narratives on the subject continued to flourish based on direct personal encounters. For example, Marcia Moore published her popular book Hypersentience in which she articulates a variety of techniques for recalling past lives. Having observed the effectiveness of hypnotic regression, Moore rejected the concept of hypnotism as a form of "negative mind control" and instead formulated a theory of past-life recall which she termed hypersentience (Moore 1975). Rather than use the term "regression," she calls past-life memories "retrocognitions" or retrocognitive recovery. This technique echoes the increasing use of hypnotic techniques to invoke past-live memories through induced ASC in ordinary clients. Moore's detailed narrative accounts of client responses provides a fascinating record of past-life (and other dimensional) experiences in which almost all clients live mundane, often impoverished, troubled, and by no means exemplary lives in difficult, frequently prejudicial, cultural circumstances. The dramas in those lives turn around the most ordinary human circumstances, often with unhealthy or deceiving human relationships, amid violent events, social upheaval, wars, bias against women and children (causing future trauma), and punctuated by happy moments and positive love relations.

The narrative theory of past lives, that is the creation of a past-life story, has become a predominant interpretative frame for speculation about out-of-body perceptions, alternate reality formations, superconscious states, and paranormal capacities-all constructed on a loose thematic assemblage of diverse narrative elements often associated with reincarnation theory. The question of imagination brings additional complexity to this assemblage because there is no denying that imagination may play a significant role in the narrative process. The link with reincarnation as a narrative context for imagining a fictive past, seems to have therapeutic value that overrides the ontological presuppositions of actual multiple lives. Nevertheless, the resulting narratives are a foundational source for further speculation and theory-building and the syncretic, thematic, narrative method is typical of many 
past-life accounts, increasingly so in contemporary writings, all divorced from any religious context (Irwin 2017, p. 328).

An outstanding syncretic and non-religious example of reincarnation theory is the writings of Jane Roberts, a very sophisticated writer, poet, and psychic explorer of the nature of consciousness. Her publications, including those under her own name and those authored by Seth, defined as an "energy essence personality" who spoke through Jane, are extensive, many dense volumes long. Jane summarized the Seth material on reincarnation in her own work, Adventures in Consciousness (1975), the core "aspect psychology" text. In this theory, the "focus personality" is the current identity of the embodied individual. However, a more deeply inherent "source-self" is the actual core of transphysical identity which manifests as a variety of "aspect selves" in various embodied and disembodied forms. The embodied forms are the physical lives, past, present, and future, of the source-self; the disembodied forms are identities immersed in other dimensional realities (Roberts 1999, pp. 95-99). Each person has many "aspects" which manifest through various incarnate lifetimes and each life is engendered and sustained by the transphysical source-self. All of these lives are concurrent.

The present "now" is the current life of the focus personality and, through psychic contact with the source-self, it is possible to perceive other lives. The interrelated lives mutually influence each other such that, in the current life, a person may influence both "past and future lives" and those lives may influence the current life. Other lives may appear as "personality aspects" (traits, characteristics, tendencies) within the current focus personality, and the source-self "can be thought of as an entity, a personified energy gestalt" that leaves "aspect prints written on the [current] psyche" (Roberts 1999, p. 100). Thus, every human being is a multidimensional being, with transphysical origins, and the embodied ego or focus personality functions in a twofold manner to coordinate with physical life and to receive inner perceptions related to the source-self and its diverse aspect prints (Irwin 2017, pp. 310-14).

Another influential individual who has strongly shaped past-life thought through popular publications is Dick Sutphen, author of You Were Born Again to Be Together (1976) and Past Lives, Future Loves (1978). Sutphen is not a medium but a facilitator who uses hypnosis to induce past-life recall in his clients, either in individual or in group sessions. Since 1971, Sutphen claims he has regressed thousands of individuals whose narratives are assembled into some interesting and creative theories about past and present lives. Subscribing to a general theory of karma as an "unerring universal law," Sutphen leads people through sessions, similar to hypersentience, into their "superconscious" mind, where explanations of current relationship issues are explored, often karmically linked to shared past events (Sutphen [1976] 2014). Sutphen theorizes that each soul may have up three or four simultaneous or overlapping lives, bound in a "soul matrix" often visualized as a linked series of past, present, or future lives. An extension of this theory is expressed in the concept of a "timeless" present in which all lives, past, present and future, are lived simultaneously, right now (citing Jane Roberts). In other words, all possible lives, including simultaneous lives, group soul lives, distant past lives, and far future lives, form a continuum that, when viewed from the timeless perspective, seem all to be active and alive concurrently. Only when the perspective shifts to a specific life does the continuum collapse, like a quantum wave function, into a local space-time condition representing the bound life and memories of one incarnation (Sutphen [1976] 2014). Additionally, Sutphen articulates a theory that each soul is a "creator" in a metaphysical sense: a single soul may generate after any one life multiple incarnations (e.g., three), and each of the three incarnations can then each generate three more incarnations, the soul dividing and multiplying progressively to form a vast tree of soul associations, any one incarnation of which might be accessed in a regression session (Sutphen 1978).

\subsection{Regression Therapy and Interlife}

Therapists also wrote popular works related to reincarnation, for example Edith Fiore, You Have Been Here Before: A Psychologist Looks at Past Lives (Fiore 1978), Helen Wambach, Reliving Past Lives (1978), and Morris Netherton, Past Lives Therapy (1978). These works all take the view that reincarnation 
theory is a meaningful perspective when applied to helping clients overcome basic personality issues, fears, maladjustment, or a wide range of emotional concerns. The narrative contents of past lives are by no means romantic or ideal, but usually narrated as traumatic, violent, ordinary, or just difficult in terms of problematic relationships and everyday hardships (Netherton [1978] 2013). The crux of past life memories is resolving old, habituated tensions and discomforts. Wambach's research is distinctive, as she used group regression techniques to see if volunteers would give historically accurate data for a variety of historical time periods based on their subjective experiences. Her basic technique was to regress a group of volunteers in stages, to selected time periods, in silent reverie, and then, upon return to normal consciousness, ask each individual to record impressions on a questionnaire of her design (Wambach [1978] 2000). Asking regressed subjects to identify such features as clothing, food, or class in various time periods resulted in a remarkably consistent portrait of a given time period, very consistent with other cultural studies of those same eras. She found, to her surprise, that only 11 out of 1088 narrative reports had any "clear evidence of discrepancies," even when conscious subjects had inaccurate views about past eras. Thus, collectively induced past-life regressions seem to correlate well with accurate historical data from those periods (Wambach [1978] 2000).

Joel Whitton and Joe Fisher's Life Between Life (1986) supports a theory of reincarnation that includes "interlife" (the period between physical lives) narratives based on Whitton's regression case histories. Whitton developed a theory of metaconsciousness as an "extraordinary state of mind" attained during the interim period by the post-mortem individual. More explicitly, he defines metaconsciousness as "an extremely paradoxical state of memory awareness" that combines both a sense of mergence or union with "existence itself" and a heightened state of self-awareness which reveals "one's reason for being" and the personal significance of karma (Whitton and Fisher 1986). In releasing the body, clients report seeing the corpse, feeling a sense of liberation (or fear), floating away into another dimension, possibly encountering a guide, attaining metaconscious awareness resulting in a swelling up of recent past-life attitudes and emotions, and then being led to a benevolent "Board of Judgment" where the soul is confronted with a panoramic review of the past life. In consultation with compassionate members of the Judgment panel, usually not more than three judges, a new "life plan" is developed based on karmic debts, occurrences in need of rebalancing, and possible new avenues of experience. A "karmic script" is developed in relationship to other individuals, including time and place of birth, parents, gender, role assumptions and other existential details (Whitton and Fisher 1986).

Many Lives, Many Masters (1988) by physician Brian Weiss is the story of one client and how her recall of past lives transformed Weiss' worldview. As a Yale University M.D. and Chief of Psychiatry at a large Miami hospital, Weiss describes himself as a conservative and a scientist. Over an 18-month period, Weiss treated Catherine (a Catholic who did not believe in rebirth) using conventional therapy for treatment of her fear-based phobias and anxiety attacks. When this failed, he then tried hypnosis. Having been regressed to the age of two in search of a cause for her fear of water, Catherine suddenly named the year $1863 \mathrm{BCE}$ as a barren place without water in where she saw herself as a young mother of a female child who was currently her niece. This rocked Weiss, who claimed to absolutely not believe in reincarnation, and Catherine, who rejected rebirth and had no knowledge of rebirth theory. Were these "memories" fantasies or imaginative constructions? The rest of the book is dedicated to a series of hypnotic sessions in which a series of lives (10-12) were articulated by Catherine. The book culminates in Weiss' belief that such narratives were not the product of psychosis, hallucination, or multiple personalities; and that their articulation, often in dramatic emotional expression, resulted in radically improved mental health (Weiss 1988).

Another example is found in the work of Roger Woolger, author of Other Lives, Other Selves: A Jungian Psychotherapist Discovers Past Lives (1988). Woolger earned a British PhD with advanced studies in philosophy, religion, and experimental psychology, trained at the C. G. Jung Institute in Zurich, and later immigrated to America as a college professor and successful psychotherapist. Woolger primarily regarded past-life regression narratives as a form of "active imagination" (without denying 
the possibility of rebirth) and defines personal identity in terms of a self-aware, conscious ego and a deeper self that unites both conscious and unconscious aspects. Taking a somewhat middle ground approach, Woolger confirms that past-life memories may be expressions of actual past lives but, even so, such memory-impressions are inseparable from normative psychological processes and have, therefore, dynamic structural aspects intrinsic to the healing process (Woolger 1988). Insofar as past-life memories may reflect actual incarnate past experience, nevertheless, fantasy, collective influences, and inherited familial or communal psychic conflicts may shape the overall complex of specific past-life memories. The healing power of catharsis and re-enactment can tap ancestral dramas and contribute to the "memory" of a given past life, or, participation in an actual past life can result in the incorporation of past collective experience into the current psychic life of the individual (Woolger 1988).

\subsection{Near Death and Out of Body Research}

Near death accounts (NDE), beginning is the 1970s and continued into the present have contributed substantively to afterlife theory and indirectly to reincarnation (Atwater 2007; Carter 2010; Moody 1975). NDE evidence offers an opening for reincarnation theory by demonstrating the plausibility of a "surviving identity" whose cognitive capacities seem not only normative but enhanced in the post-mortem state (Greyson 2010). The most common NDE qualia are: a sense of separation from the physical body as a discreet mobile identity (OBE); intensification of feelings; lucid awareness of local physical surroundings; movement away from those surrounding, often into or through a velvet darkness; encountering a non-ordinary realm inhabited by postmortem others, including relatives, friends, animals, and "beings of light" who are perceived as helpful and supportive; intense feelings of peace, calm, and joy; and in deeper NDE, a cosmic encounter with Light, God, or other manifestations of great ontological import for the experient. These qualia are noted as occurring while the experient is clinically dead, that is in a medical context having no heartbeat, no eye reflex, no breathing and no measurable brain activity (Irwin 2017, p. 361). If there is a surviving identity apart from the physical body, as illustrated in thousands of NDE cases, then reincarnation is a possible outcome intrinsic to an afterlife process (Holden et al. 2009).

The out-of-body (OBE) aspect of the data refers to the state of an individual who can differentiate between his or her physical body and another more etheric "body-like form" that seems to have all the normative sensory functions of an embodied consciousness. The OBE often results in contact with post-mortem domains inhabited by a wide variety of entities, spirits, or deceased individuals. Insofar as a "projected self" can seemingly enter alternate worlds and return with lucid memory of such encounters, such a self may be an entity that survives death and, if so, then such encounters may support reincarnation theories (Irwin 2017). The best example is found in the writings of Robert Monroe whose "out of the body" narratives make a direct connection with reincarnation. Monroe lays out not only a theory of reincarnation but a topological description of afterlife domains that impinge upon and condition the cycles of death and rebirth. Monroe $(1985,1994)$ outlines a complex system of hierarchical domains, ranging from near physical earth-life, to an intermediary zone where the individual recognizes being dead, to a much vaster nonphysical domain (or "Belief System Territories") consisting of many sub-domains based on shared, communal beliefs. Post-mortem individuals tend to gravitate to sub-domains consistent with their dominant beliefs. The highest quasi-transhuman zone consists of "Last Timers" who are preparing for one final physical incarnation, after which the entity is free to explore even more advanced domains beyond the human world. Monroe claims to have visited and explored all these domains via OBE (Monroe 1994).

The elaboration of meta-domains of post-mortem life has continued to gain in popularity, not only from NDE and OBE narratives, but also from a specific technique in regression therapy structured around the interlife period. The best example is found in the popular publications of regression therapist Dr. Michael Newton (Newton 2001) who draws a specific parallel between OBE, NDE, and hypnotized clients talking about interlife experiences as a prelude to reincarnation. Newton's writing is strongly didactic, based on his own client cases and is replete with many leading questions during 
hypnosis, resulting is a fixed, paradigmatic psychocosm that becomes the archetype for all human dead (irrespective of culture, ethnicity, or religion). Hypnotic regression, for Newton, is a means for accessing "superconsciousness," thereby acquiring multiple memories of existence in-between lives for any given individual client. Drawing upon his many cases, he assembles the material into discreet stages, based on specific visualization techniques that result in a composite, idealized view of the entire interlife process (not found in any one case)—which he sees as reinforced by narratives from OBE and NDE research, as well as past-life studies.

Newton's interlife stages are as follows: death and exiting the body (OBE); entering a near (lower) astral plane with awareness of local embodied life; "homecoming" (being met by transphysical others in a welcoming sense, what he terms "our reception committee"); the dispersion of "displaced souls" (the separation of souls "severely damaged," consisting of two types: haunting ghosts who resist advancement and those separated from others for "rehabilitation" in "a kind of purgatory") (Newton 2001). This leads to "orientation," which he describes as "a healing station" that involves "substantial counseling with one's guide," a "debriefing" to help the soul readjust to returning to the spirit world, "gentle but probing," where the previous incarnation's "performance is judged" in order to reveal strengths and weaknesses. This judgment, similar to Whitton's theory, occurs before a "panel of superior, wise beings," or "Council of Elders," consisting of three to seven members who examine the soul's conduct, with a guide acting as an advocate for the soul. This judgment usually occurs during "transition" in a "staging area," a vast interlife domain of many sub-domains, as in Robert Monroe, a hub of interlinked, transferring souls heading for specific sub-domains or group placement in "spiritual schools directed by teacher-guides" (Newton 2001, pp. 71-86). Working within a "maze of karmic issues," an individual must eventually select a body, gender, and family consistent with his or her "blueprint for the next life" developed with guides and soul-group members (as in Whitton). The selection may include choices for certain limitations, illnesses, or deficient conditions to strengthen soul development and to balance karmic debts (Newton 2001).

Clearly, the increasing popularity of reincarnation theory among various advocates of OBE and NDE narratives, coupled with evidential data from significant medical personnel, professional therapists, and scholarly, research-based analysis of relevant materials, has challenged conventional ideas about consciousness, personhood, and transphysical human identity (Irwin 2017). Academic philosophers have entered the fray, disputing theories and attacking or defending the plausibility of reincarnation, with parapsychologists mediating the stretch between competing theories. There are primarily only three such current theories: the materialist position of consciousness as utterly dependent upon and caused by a physical body and brain with a variety of epiphenomenal, eliminative, parallelist, and mentalist interpretations; therefore, reincarnation cannot possibly be true. Second, there are several types of dualism such as the Cartesian mind/matter distinction between an individual mind and a specific body, or more subtly "interactionism," in which mind or psyche may directly influences neural events; thus, dualism leads to survival theory in which (at the very least) some mental aspects of identity survive death. And third, the heightened psi theory that argues that all accounts of survival, mediumship, past-life recall, and so on, can be attributed to very developed ESP abilities such as telepathy, clairvoyance, or psychokinesis, as carried out by living, embodied individuals. This "super-psi" theory throws into question the legitimacy of reincarnation (and survival), while not denying the value and significance of psychic perceptions (Beauregard and O'Leary 2007; Braude 2003; Irwin 2017, pp. 369-70).

\section{Conclusions}

The history of belief in reincarnation, in the American context, reveals a complex pattern of interactive influences moving toward an increasing detachment from any specific religious tradition. Over the last fifty years, reincarnation theory has been increasingly identified with personal experience, therapeutic practices, paranormal studies, fictive or imaginative accounts, and a wide variety of American metaphysical teachings strongly influenced by esoteric ideas and organizations. This does 
not mean, however, that we have a coherent theory of reincarnation (Irwin 2017). In fact, what we have are many convergent and contradictory views as well as some ill-defined or idiosyncratic, unprovable theories that lack conclusive evidence beyond the descriptive narrative of the propagators of those theories. If reincarnation theory is a suppositional or propositional construction that seeks to offer a plausible ontological account based on information, from diverse lines of research, then such theory is also subject to revisions based on additional information that might challenge original assumptions (Irwin 2017, p. 395). In this sense, reincarnation is a provisional theory with many alternative constructions.

The history of reincarnation theory has been moving away from doctrinal accounts and into a more mediated area in which personal, participatory events linked to paranormal studies offer a wealth of data for the formulation and reformulation of theory. However, there is another issue in which more ordinary accounts (as in regression therapy) are juxtaposed to accounts by those with unique capacities to interpret rebirth theory based on exceptional perceptual abilities. Paranormal studies clearly demonstrate that some persons have unique forms of participatory encounter, including NDE and OBE experiences (Palmer and Hastings 2013). To what degree is "special knowledge" or unique psychic capacities necessary for the formulation of theory? There is also the question of karma. Most theory of karma is remarkable simple and underdeveloped. Karmic influences as "causal" are surely part of a much larger, complex universe of interactive influences that far exceeds any linear theory that would equate action A with a given (post-mortem) effect B. Thus "an eye for eye and a tooth for a tooth" is not a working model for karmic influences. What exactly are the causal influences that might shape a future life based on a holistic theory of causal effects? A complexity model of karma might consider a multitude of influences in a "tangled hierarchy" of cross-related causes linked together by long-term relationships, collective developments, catastrophic events, climate change, cultural and historical transformation, ethnic differences, gender diversity, genetic coding, and a vast range of subtle psychic interaction. No such model currently exists.

In the cosmological sense, reincarnation theory points toward a "metacosm" in which there are multiple possible domains of lived, post-mortem experience. Such a cosmology is not reducible to the visible, even instrumental, observable physical universe. All reincarnation theories posit an interim period of existence in variable domains which tend to conform to or resonate with the beliefs and values of the post-mortem individual. In those domains, post-mortem individuals express a wide range of perceptual and cognitive functions, as well as distinctive motivations, desires, and a capacity, in some models, for learning and development. These alternate domains do not coincide; they seem to reflect cultural patterns and beliefs to some degree but they also appear to be uniquely distinctive, and thus only partially shaped by former embodied contexts. Perhaps there are multiple post-mortem domains, each coexisting as unique expressions of a unified, multidimensional metacosm. The interim between incarnation is also dynamic in the sense that most theories express a view that there are stages of transformation and an opportunity, or a compulsion, for return to another embodied life (Irwin 2017, pp. 396-400).

As a plausible theory, reincarnation challenges materialist views that deny all forms of survival and post-mortem existence. The denial of rebirth cannot be demonstrated or proven; it can only be a statement of belief with very little evidence to support its actuality. However, the contestation is not about belief as much as it is about evidential sources that might support a positive theory of survival and thus, possibly rebirth. The pervasiveness of rebirth accounts collectively challenges the minority views of materialist ideologues when brought into alignment with all the various strands of evidence that contribute to a transphysical model of human survival. While no one source may provide a convincing argument in favor of post-mortem life and rebirth, together all sources provide a strong collective body of evidence supporting the plausibility of survival as a valid theory, currently held by a majority of human beings. If there is survival, then there may be rebirth. While the two theories do not necessarily support each other (survival and rebirth), nevertheless, survival imputes a capacity for rebirth when linked to participatory narratives claiming evidential knowledge of 
explicit past-life experience (Irwin 2017, pp. 400-3). Evidential sources from diverse fields of research, as well as a growing body of ethnographic and therapeutic accounts, strongly supports a historical trajectory in which reincarnation has become an increasingly believable possibility without dependency upon any specific religious convictions. Overall, reincarnation beliefs have increased in complexity, become intrinsic to a wide array of afterlife theories, and garnered increasing attention from multiple academic disciplines.

Conflicts of Interest: The author declares no conflict of interest.

\section{References}

Abhedananda, Swami. 1907. Vedanta Philosophy: Five Lectures on Reincarnation. New York: The Vedanta Society, Available online: https:/ / archive.org/details/vedantaphilosop02abhegoog (accessed on 9 August 2017).

Adams, Edward C. 1927. Congaree Sketches. Chapel Hill: The University of North Carolina Press.

Albanese, Catherine. 1997. Dissent History: American Religious Culture and the Emergence of the Metaphysical Tradition. In Religious History: Studies in Tradition and Cultures. Edited by Walter H. Conser Jr. and Sumner B. Twiss. Athens: University of Georgia Press, pp. 157-88.

Arnold, Sir Edwin. 1879. The Light of Asia. Tullera: Buddha Dharma Education Association, Inc., Available online: http:/ / www.buddhanet.net/pdf_file/lightasia.pdf (accessed on 9 August 2017).

Atkinson, William W. 1908. Reincarnation and the Law of Karma. Chicago: Yogi Publication Society. Available online: https:/ / play.google.com/books/reader?printsec=frontcover\&output=reader\& id=HOA1AQAAMAAJ\&pg=GBS.PA1 (accessed on 9 August 2017).

Atwater, A. Phyllis. 2007. The Big Book of Near-Death Experiences. Charlottesville: Hampton Roads Publishing Company.

Beauregard, Mario, and Denyse O'Leary. 2007. The Spiritual Brain: A Neuroscientist's Case for the Existence of Soul. New York: HarperCollins.

Blavatsky, Helena. 1882. Isis Unveiled and the Theosophist on Reincarnation. Theosophist 3: 288-89. Available online: http:/ /www.katinkahesselink.net/blavatsky/articles/v4/y1882_091.htm (accessed on 8 August 2017).

Bose, Ram Chandra. 1884. Hindu Philosophy Popularly Explained: The Orthodox Systems. New York: Funk \& Wagnalls.

Braude, Stephen E. 2003. Immortal Remains: The Evidence for Life after Death. Lanham: Rowman \& Littlefield.

Bremmer, Jan. 1983. The Early Greek Concept of Soul. Princeton: Princeton University Press.

Carter, Chris. 2010. Science and the Near-Death Experience. Rochester: Inner Traditions.

Cerminara, Gina. 1950. Many Mansions: The Edgar Cayce Story of Reincarnation. New York: New American Library.

Clark, Mary Ann. 2007. Santería: Correcting the Myths and Uncovering the Realities of a Growing Religion. Westport: Praeger.

Copenhaver, Brain P. 1998. Hermetica. New York: Cambridge University Press.

Corrigan, John Michael. 2012. American Metempsychosis: Emerson, Whitman, and the New Poetry. New York: Fordham University Press.

Coudert, Allison P. 1976. A Quaker-Kabbalist Controversy: George Fox's Reaction to Francis Mercury van Helmont. Journal of the Warburg and Courtauld Institutes 39: 171-89. [CrossRef]

Coudert, Allison P. 1999. The Impact of the Kabbalah in the Seventeenth Century: The Life and Thought of Francis Mercury van Helmont (1614-1698). Leiden: Brill.

Coudert, Allison. 2008. The Kabbalah, Science, and the Enlightenment: The Doctrines of Gilgul and Tikkun as Factors in the Anthropological Revolution of the Eighteenth Century. In Aufklärung und Esoterik: Rezeption-Integration—Konfrontation. Edited by Monika Neugebauer-Wölk. Tübingen: Max Niemeyer, pp. 299-316.

Curtiss, F. Homer. 1949. Reincarnation. San Gabriel: Willing Publishing Company.

De La Torre, Miguel. 2004. Santería. Grand Rapids: Wm. B. Eerdmans Publishing.

Détré, Jean-Marie. 2005. La Réincarnation et L'Occident. Tome II; Paris: Éditions Triades.

Dharmapala, Anagarika. 1999. The World's Debt to Buddha. In Asian Religions in America: A Documentary History. Edited by Thomas Tweed and Stephen Prothero. New York: Oxford University Press, pp. 133-37. 
Dodds, Eric Robertson. 1962. The Greeks and the Irrational. Oakland: University of California Press.

Ellwood, Robert, ed. 1987. Eastern Spirituality in America: Selected Writings. New York: Paulist Press.

Evans-Wentz, Walter, ed. 1960. The Tibetan Book of the Dead: Or The After-Death Experiences on the Bardo Plane. Translated by Kazi Dawa-Samdup. Oxford: Oxford University Press. First published 1927.

Fiore, Edith. 1978. You Have Been Here Before: A Psychologist Looks at Past Lives. New York: Ballentine Books.

Fisher, Elizabeth W. 1985. Prophesies and Revelations: German Cabbalists in Early Pennsylvania. The Pennsylvania Magazine of History and Biography 109: 299-334.

Fulk, Augustus Marion. 1940. Reincarnation: Time, Space, Matter. Boston: The Christopher Publishing House.

Fuller, Margaret, ed. 1843-1844. The Dial: A Magazine for Literature, Philosophy, and Religion. Boston: E. P. Peabody, vols. 3,4 .

Givens, Terry L. 2010. When the Soul Had Wing: Pre-mortal Existence in Western Thought. New York: Oxford University Press.

Goudey, Ray. F. 1928. Reincarnation: A Universal Truth. Los Angeles: The Aloha Press.

Graf, Fritz, and Sarah Iles Johnston. 2007. Ritual Texts for the Afterlife: Orpheus and the Bacchic Gold Tablets. London: Routledge Press.

Greyson, Bruce. 2010. Implications of Near-Death Experiences for a Postmaterialist Psychology. Psychology of Religion and Spirituality 2: 37-45. [CrossRef]

Hall, Manly Palmer. 2010. The Secret Teachings of All Ages: An Encyclopedic Outline of Masonic, Hermetic, Qabbalistic and Rosicrucian Symbolical Philosophy. New York: Dover Publications. First published 1928.

Hall, Manly Palmer. 1999. Reincarnation: The Cycles of Necessity. Los Angeles: The Philosophical Research Society. First published 1939.

Head, Joseph, and Sylvia Cranston, eds. 1967. Reincarnation: A Living Study of Reincarnation in All Ages Including Selections from the World's Religions, Philosophies, and Sciences, and Great Thinkers of the Past and Present. New York: Julian Press.

Head, Joseph, and Sylvia Cranston, eds. 1990. Reincarnation: An East-West Anthology. Wheaton: The Theosophical Publishing House.

Heindel, Max. 1973. The Rosicrucian-Cosmo-Conception. Oceanside: The Rosicrucian Fellowship International Headquarters. First published 1909.

Hildebrand, Jennifer. 2006. “Dere Were No Place in Heaven for Him, an' He Were Not Desired in Hell," Igbo Cultural Beliefs in African American Folk Expressions. The Journal of African American History 91: 127-52. Available online: https:/ / www.jstor.org/stable/20064067?seq=1\#page_scan_tab_contents (accessed on 8 August 2017).

Holden, Janice M., Bruce Greyson, and Debbie James, eds. 2009. The Handbook of Near-Death Experiences: Thirty Years of Investigation. Santa Barbara: Praeger Publishers.

Howe, Quincy. 1974. Reincarnation for the Christian. Wheaton: The Theosophical Publishing House.

Hubbard, L. Ron. 2007. Scientology: The History of Man. Commerce: Bridge Publications. First printed 1950.

Hultkrantz, Ake. 1953. Conceptions of the Soul among Native North Americans: A Study in Religious Ethnology. Stockholm: Ethnographical Museum of Sweden. ASIN: B007F5YB6C.

Hultkrantz, Ake. 1998. Soul and Native Americans. Washington: Spring Publications. ISBN-10: 0882142232.

Hyslop, James H. 1906. The Borderland of Psychic Research. Boston: Herbert B. Turner \& Co.

Irwin, Lee. 2017. Reincarnation in America: An Esoteric History. Lanham: Lexington Books (Rowman and Littlefield). ISBN-10: 1498554075. Available online: https://rowman.com/ISBN/9781498554077/Reincarnation-inAmerica-An-Esoteric-History (accessed on 15 September 2017).

Jackson, Carl T. 1981. The Oriental Religions and American Thought: Nineteenth-Century Explorations. Westport: Greenwood Press.

Johnston, Charles. 1899. The Memory of Past Births. New York: The Theosophical Society, Available online: http:/ / books.google.com/books?id=FP8LAAAAIAAJ\&printsec=frontcover\&dq=the+memory+of+past+ births\&hl=en\&sa=X\&ei=qNnRUYCyM43C9gSz6oCAAw\&ved=0CDUQ6AEwAA\#v=onepage\&q\&f=false (accessed on 9 August 2017).

Johnston, Sarah Iles. 2011. In Praise of Disorder: Plato, Eliade, and the Ritual Implications of a Greek Cosmogony. In Archiv für Religionsgeschichte. Edited by John Assman and John Scheid. Berlin: De Gruyter, pp. 51-60.

Judge, William Q. 1987. The Ocean of Theosophy. Los Angeles: The Theosophy Company. First published 1893.

Kaplan, Steven, ed. 1996. Concepts of Transmigration. Lewiston: The Edwin Mellon Press. 
Kardec, Allan. 1950. The Spirit's Book (Le Livre des Esprits). Translated by Anna Blackwell. Sao Paulo: Lake Publishing. First published 1857.

Kardec, Allan. 1987. The Gospel According to Spiritism. Translated by J. A. Duncan. London: The Headquarters Publishing Co. First published 1857.

Karr, Don. 2010. The Study of Christian Cabala in English. Available online: http:/ /www.digital-brilliance.com/ kab/karr/ccinea.pdf (accessed on 6 August 2017).

Keith, George. 1692. Truth and Innocency Defended against Calumny and Defamation, in a Late Report Spread Abroad Concerning the Revolution of Humane Souls. Philadelphia: William Bradford. Available online: http: / / quod.lib.umich.edu/e/eebo/A47190.0001.001?view=toc (accessed on 6 August 2017).

Langley, Noel. 1967. Edgar Cayce on Reincarnation. New York: Warner Books.

Larson, Kerry. 2001. Individualism and the Place of Understanding in Emerson's Essays. English Literary History 68: 991-1021. [CrossRef]

Layton, Bentley. 1987. The Gnostic Scriptures. New York: Doubleday.

Leijenhorst, Cees. 1998. Francesco Patrizi's Hermetic Philosophy. In Gnosis and Hermeticism from Antiquity to Modern Times. Edited by Roelof Van Den Broek and Wouter J. Hanegraaff. Albany: State University of New York Press, pp. 127-34.

Lewis, H. Spencer. 1956. Mansions of the Soul: The Cosmic Conception. San Jose: Supreme Lodge of AMORC. First published 1930.

Logan, Alastair B. 1996. Gnostic Truth and Christian Heresy. Peabody: Hendrickson Publishers.

Long, Herbert S. 1948. A Study of the Doctrine of Metempsychosis in Greece from Pythagoras to Plato. PhD. dissertation, Princeton University, Princeton, NJ, USA.

Lopez, Donald. 1998. Prisoners of Shangri-La: Tibetan Buddhism and the West. Chicago: The University of Chicago Press.

Lopez, Donald. 2011. The Tibetan Book of the Dead: A Biography. Princeton: Princeton University Press.

MacGregor, Geddes. 1978. Reincarnation in Christianity: A New Vision of the Role of Rebirth in Christian Thought. Wheaton: The Theosophical Publishing House.

Mazama, Mambo Ama. 2002. Afrocentricity and African Spirituality. Journal of Black Studies 33: 218-34. [CrossRef] Mbiti, John S. 1970. African Religions and Philosophy. New York: Doubleday \& Company.

Mead, George R. S. 1989. Pistis Sophia: A Gnostic Gospel. Blauvet: Spiritual Science Library. First published 1896.

Mendoza, Ramon G. 1995. The Acentric Labyrinth: Giordano Bruno's Prelude to Contemporary Cosmology. Rockport: Element Books Limited.

Mills, Antonia. 1994. Rebirth and Identity: Three Gitksak Cases of Pierced-Ear Birthmarks. In Amerindian Rebirth: Reincarnation Belief among North American Indians and Inuit. Edited by Antonia Mills and Richard Slobodin. Ontario: University of Toronto Press, pp. 211-41.

Mills, Antonia, and Richard Slobodin, eds. 1994. Amerindian Rebirth: Reincarnation Belief among North American Indians and Inuit. Toronto: University of Toronto Press.

Monroe, Robert. 1985. Far Journey. Garden City: Doubleday.

Monroe, Robert. 1994. Ultimate Journey. New York: Doubleday.

Moody, Raymond. 1975. Life after Life. Atlanta: Mockingbird Books.

Moore, Marcia. 1975. Hypersentience: Exploring Your Past-lifetime as a Guide to Your Character and Destiny. New York: Crown Publishers.

Muller, F. Max, ed. 1879-1910. The Sacred Books of the East. 50 vols. Oxford: The Clarendon Press.

Netherton, Morris. 2013. Past Lives Therapy, Kindle ed. Seattle: Amazon Digital Services. First published 1978.

Newton, Michael. 2001. Journey of the Soul: Case Studies in Life between Lives. St. Paul: Llewellyn Publications.

Obuchowski, Peter A. 1979. Emerson, Evolution, and the Problem of Evil. The Harvard Theological Review 72: 150-56.

Ogren, Brian. 2009. Renaissance and Rebirth: Reincarnation in Early Modern Italian Kabbalah. Leiden: Koninklijke Brill NV.

Olcott, Henry Steele. 1886. A Buddhist Catechism, According to the Sinhalese Canon. Madras: Graves, Cookson, and Company. First published 1881.

Olmos, Margarite F., and Lizabeth Paravisini-Gebert. 2003. Creole Religions of the Caribbean: An Introduction from Vodou and Santeria to Obeah and Espiritismo. New York: New York University Press. 
Onyewuenyi, Innocent. 1996. African Belief in Reincarnation: A Philosophical Appraisal. Lexington: BookSurge Publishing.

Palmer, Genie, and Arthur Hastings. 2013. Exploring the Nature of Exceptional Human Experiences. In The Wiley Blackwell Handbook of Transpersonal Psychology. Edited by Harris L. Friedman and Glenn Hartelius. Malden: John Wiley \& Sons, Ltd., pp. 333-51.

Pearson, Birger A. 2007. Ancient Gnosticism: Traditions and Literature. Minneapolis: Fortress Press.

Peréz, Elizabeth. 2011. Spiritist Mediumship as Historical Mediation: African-American Pasts, Black Ancestral Presence, and Afro-Cuban Religions. Journal of Religion in Africa 41: 330-65. [CrossRef]

PEW. 2009. Many American Mix Multiple Faiths. Washington: PEW Research Center: Religion \& Public Life. Available online: http:/ / www.pewforum.org/2009/12/09/many-americans-mix-multiple-faiths / (accessed on 13 August 2017).

Pike, Albert. 2005. Morals and Dogma of the Ancient and Accepted Scottish Rite Freemasonry. Whitefish: Kessinger Publishing. First published 1872.

Preston, William. 2016. Illustrations of Masonry. Reprint of 1867 edition; New Orleans: Cornerstone Book Publishers.

Prophet, Elizabeth Clare. 1997. Reincarnation: The Missing Link in Christianity. Corwin Springs: Summit University Press.

Pryse, James. 1911. Reincarnation in the New Testament. New York: Theosophical Publishing.

Raboteau, Albert J. 2004. Slave Religion: The "Invisible Institution" in the Antebellum South. New York: Oxford University Press. First published 1978.

Randolph, Paschal B. 2012. Dealings with the Dead: The Human Soul, Its Migrations and Transmigrations. Hong Kong: Forgotten Books. First published 1862. Available online: https:/ / archive.org/details/DealingsWithTheDead (accessed on 9 August 2017).

Remes, Pauliina. 2008. Neoplatonism. Berkeley: University of California Press.

Rhys-Davids, Thomas William. 1912. Buddhism: Being a Sketch of the Life and Teachings of Gautama. London: Society for Promoting Christian Knowledge. First published 1877.

Rhys-Davids, Thomas William. 1878. Buddhist Birth Stories: Jataka Tales. London: George Routledge \& Sons. Available online: https:/ / archive.org/details/buddhistbirth00daviuoft (accessed on 9 August 2017).

Roberts, Jane. 1999. Adventures in Consciousness: In Introduction to Aspect Psychology. Needham: Moment Point Press.

Rosán, Laurence. 2008. The Philosophy of Proclus: The Final Phase of Ancient Thought. Wiltshire: Prometheus Trust.

Salisbury, Edward E. 1847. M. Burnouf on the History of Buddhism in India. Journal of the American Oriental Society 1: 275-98. Available online: https:/ / archive.org/details/jstor-3217805 (accessed on 10 August 2017). [CrossRef]

Sandoval, Mercedes Cros. 2007. Worldview, the Orishas, and Santeria. Gainesville: University of Florida Press.

Smith, Robert C. 1989. Edgar Cayce: You Can Remember Your Past Lives. New York: Warner Books.

Sorabji, Richard. 2005. The Philosophy of the Commentators: 200-600 AD. Ithaca: Cornell University Press, vol. 1.

Stevenson, Ian. 1966. Twenty Cases Suggestive of Reincarnation. New York: American Society for Psychical Research, vol. 26.

Stevenson, Ian. 1975. The Belief and Cases Related to Reincarnation Among the Haida. Journal of Anthropological Research 31: 364-75. [CrossRef]

Stevenson, Ian. 1983. American Children Who Claim to Remember Previous Lives. The Journal of Nervous and Mental Disease 171: 742-48. [CrossRef] [PubMed]

Stevenson, Ian. 1997. Where Reincarnation and Biology Intersect. 2 vols. Westport: Praeger Publishers.

Sutphen, Dick. 2014. You Were Born to Be Together, Kindle ed. New York: Pocket Books. First published 1976.

Sutphen, Dick. 1978. Past Lives, Future Loves. New York: Pocket Books.

Taylor, Eugene. 1999. Shadow Culture: Psychology and Spirituality in America. Washington: Counterpoint Press.

Twitchell, Paul. 1969. Eckankar: The Key to Secret Worlds. San Diego: Illumined Way Press.

Versluis, Arthur. 2001. Esoteric Origins of the American Renaissance. New York: Oxford University Press.

Walker, D. P. 1954. The Prisca Theologia in France. Journal of the Warburg and Courtauld Institutes 17: $204-59$. [CrossRef]

Wambach, Helen. 2000. Reliving Past Lives: The Evidence under Hypnosis. New York: Barns \& Nobles. First published 1978. 
Warren, Henry Clarke. 1922. Buddhism in Translation. Cambridge: Harvard University Press. First published 1896. Available online: http:/ / books.google.com/books?id=7rooAAAAYAAJ\&pg=PR9\&dq=warren+buddhist\&

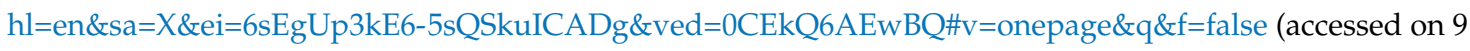
August 2017).

Weiss, Brian. 1988. Many Lives, Many Masters. New York: Simon \& Schuster.

Translated by David M. Wexelman. 1999, The Jewish Concept of Reincarnation and Creation [Sha'ar ha Gilgulim]. Northwale: Jason Aronson. Available online: http:/ / www.chabad.org/kabbalah/articlecdo/aid/380302/ jewish/Gate-of-Reincarnations-Introduction.htm (accessed on 6 August 2017).

Whitton, Joel, and Joe Fisher. 1986. Life between Life. New York: Warner Books.

Woolger, Roger. 1988. Other Lives, Other Selves: A Jungian Psychotherapist Discovers Past Lives. New York: Bantam. Yogananda, Paramahansa. 1979. Autobiography of a Yogi. Los Angeles: Self-Realization Fellowship. First published 1946.

C 2017 by the author. Licensee MDPI, Basel, Switzerland. This article is an open access article distributed under the terms and conditions of the Creative Commons Attribution (CC BY) license (http://creativecommons.org/licenses/by/4.0/). 